\title{
Preparation and characterization of nano-hydroxyapatite powder using sol-gel technique
}

\author{
K P SANOSH ${ }^{\dagger}$, MIN-CHEOL CHU, A BALAKRISHNAN ${ }^{\dagger}$, T N $\mathrm{KIM}^{\dagger}$ and \\ SEONG-JAI CHO* \\ Division of Metrology for Emerging Technology, Korea Research Institute of Standards and Science, \\ 1 Doryong-Dong, Yuseong-Gu, Daejeon 305-340, Republic of Korea \\ ${ }^{\dagger}$ Department of Information and Electronic Materials Engineering, College of Engineering, Paichai University, \\ Daejeon 302-735, Republic of Korea
}

MS received 29 August 2008; revised 12 December 2008

\begin{abstract}
Hydroxyapatite (HA) nano powders $(20-60 \mathrm{~nm})$ were synthesized using a sol-gel route with calcium nitrate and phosphoric acid as calcium and phosphorus precursors, respectively. Double distilled water was used as a diluting media for $\mathrm{HA}$ sol preparation and ammonia was used to adjust the $\mathrm{pH}$. After aging, the HA gel was dried at $65^{\circ} \mathrm{C}$ and calcined to different temperatures ranging from $200-800^{\circ} \mathrm{C}$. The dried and calcined powders were characterized for phase composition using $\mathrm{X}$-ray diffractometry, elemental dispersive $\mathrm{X}$-ray and Fourier transform infra-red spectroscopy. The particle size and morphology were studied using transmission electron microscopy. Calcination revealed HA nano powders of increased particle size and crystallinity with increase in temperature. For all calcinations temperatures, the particle size distribution analysis of HA powders showed skewed distribution plot. At temperature of $700^{\circ} \mathrm{C}$ and above, formation of $\mathrm{CaO}$ was noticed which was attributed to phosphorous volatilization. This study showed that high purity HA with varying degrees of crystallinity could be obtained using this simple technique.
\end{abstract}

Keywords. Hydroxyapatite; particle size; sol-gel; calcination; phase purity; crystallinity.

\section{Introduction}

Hydroxyapatite (HA) has attracted much attention as a material for artificial bones (Hench 1998), scaffolds for tissue engineering (Ebaretonbofa and Evans 2002; Li et al 2002) and chromatographic packing (Kawasaki 1999) because of its high bioactivity and particular adsorbability for various ions and organic molecules. Due to the chemical similarity between HA and mineralized bone of human tissue, synthetic HA exhibits strong affinity to host hard tissues. Formation of chemical bond with the host tissue offers HA a greater advantage in clinical applications than most other bone substitutes, such as allografts or metallic implants (Itokazu et al 1998; Minguez et al 1990). However, due to poor mechanical properties of HA the recent trend in bioceramic research is focused on improving their mechanical and biological properties using nanotechnology. It has been reported that the resorption process of HA is quite different from that of bone mineral. Bone mineral crystals are nano-sized with a very large surface area. These crystals are grown in an organic matrix and have very loose crystal to crystal

\footnotetext{
*Author for correspondence (the_krecian@yahoo.com)
}

bonds. Therefore, the resorption by osteoclasts is quite homogeneous. On the contrary, micro-size HA presents a low surface area and have strong crystal-to-crystal bond. In addition, the bone mineral shows higher bioactivity compared with crystalline HA (Kim 2003). Moreover, studies on the in vitro and in vivo $\mathrm{Ca}^{2+}$ ion release (Murugan and Ramakrishna 2004) from the nano HA powders were found to be similar to bone apatite and significantly faster than microscale sized counterparts. Thus engineering HA at nano-level would have superior functional properties due to its grain size, large surface area to volume ratio and crystallinity similar to biological apatite, which would have a greater impact on implant-cell interaction in body environment (LeGeros 1991). Hence extensive efforts have been made to produce synthetic nano-HA materials (LeGeros 1991). Common methods used to produce synthetic nanocrystalline HA include precipitation (Saeri et al 2003), hydrothermal (Masahiro et al 1994), hydrolysis (Shih et al 2004), mechanochemical (Silva et al 2003) and sol-gel (Kim and Kumta 2004). These techniques can generate nano to micrometric size HA crystals (Dean-Mo et al 2001; Afshar et al 2003). However, sol-gel (Kim and Kumta 2004) method offers a distinct advantage of a molecular-level mixing of the calcium and phosphorus precursors, which is capable of 
improving chemical homogeneity of the resulting HA to a significant extent, in comparison with above conventional techniques. Furthermore, the high reactivity of the solgel powders results in the decrease of the calcining and sintering temperatures (Dean et al 2002). In the present work, the synthesis of a nanosize HA powder via sol-gel method was prepared using calcium nitrate tetrahydrate, phosphoric acid $\left(\mathrm{H}_{3} \mathrm{PO}_{4}\right)$ and ammonia as starting precursors. Pure HA nano powders were obtained at $65-600^{\circ} \mathrm{C}$.

\section{Experimental}

In the present study, calcium nitrate tetrahydrate $\left(\mathrm{Ca}\left(\mathrm{NO}_{3}\right)_{2} \cdot 4 \mathrm{H}_{2} \mathrm{O}\right)(\mathrm{CNT})$ (Junsei chemicals Co., Ltd., S. Korea), phosphoric acid $\left(\mathrm{H}_{3} \mathrm{PO}_{4}\right)$ (PA) (Samchun Pure Chemicals Co., Ltd, S. Korea) and ammonia $\left(\mathrm{NH}_{3}\right)$ (Daejung Chemicals and Metals Co. Ltd., S. Korea) were used as starting precursors. The schematic presentation of the procedure is given in figure 1. Firstly, $0.25 \mathrm{M}$ PA was prepared in double distilled water. To this solution, ammonia was added and stirred till a constant $\mathrm{pH}=10$ was obtained. $1 \mathrm{M} \mathrm{CNT}$ was prepared by completely dissolving it in double distilled water. This CNT solution was slowly added to the above PA-ammonia solution, maintaining a $\mathrm{Ca} / \mathrm{P}$ ratio of $1 \cdot 67$. The solution was kept constant at $\mathrm{pH}=10$ by further adding small amounts of ammonia. The solution was rigorously stirred for $1 \mathrm{~h}$ and kept for ageing for $24 \mathrm{~h}$ at room temperature. The gel obtained after aging was dried at $65^{\circ} \mathrm{C}$ for $24 \mathrm{~h}$ in a dry oven. The powders from dried gel were washed repeatedly using double distilled water to remove $\mathrm{NH}_{4}^{+}$and $\mathrm{NO}_{3}^{-}$. After washing, the powder was calcined in air at different temperatures ranging from $200-800^{\circ} \mathrm{C}$ for $30 \mathrm{~min}$ using an electrical furnace and employing a heating rate of $10^{\circ} \mathrm{C} / \mathrm{min}$. Transmission electron microscope (TEM)

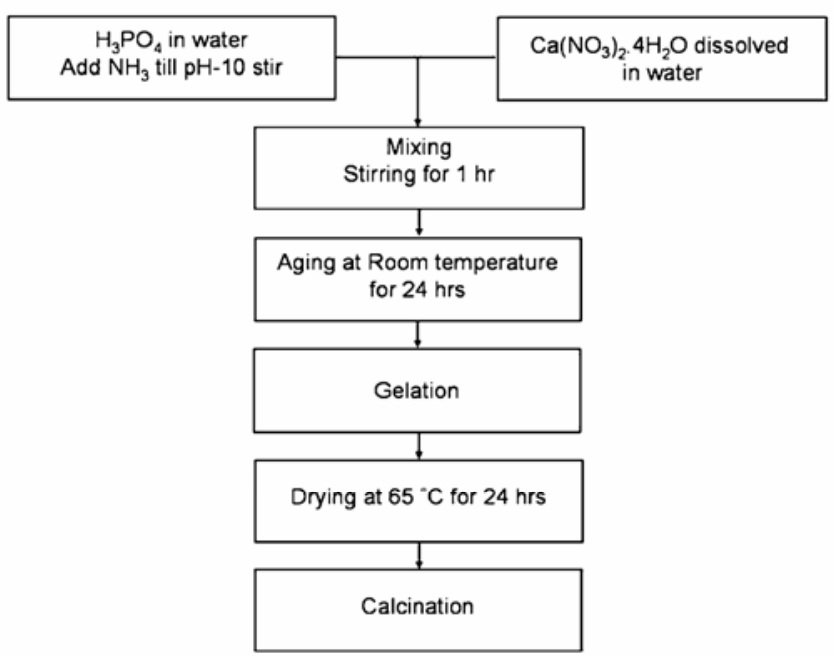

Figure 1. Flow chart of hydroxyapatite preparation by the sol-gel route.
(HR-TEM, Model Tecnai-Philips F30, FEI Co., Hillsboro) was used to observe the morphology and the particle size of calcined HA powders. Elemental phase composition of the HA powder was analyzed using energy dispersive X-ray (EDX) (SEM-EDX, ISI-DS130C dual stage SEM, Akashi, Japan). The X-ray diffraction (XRD) pattern of the final HA nanoparticles was obtained with $\mathrm{CuK} \alpha$ radiation $(\lambda=1.5418 \AA$ ) on a D8 Advance (Bruker-AXS, Germany) diffractometer and then analysed using Ni-filtered $\mathrm{CuK} \alpha$ radiation $(\lambda=0.1542 \mathrm{~nm})$, in the step scanning mode, with tube voltage of $40 \mathrm{kV}$ and tube current of $50 \mathrm{~mA}$. The XRD patterns were recorded in the $2 \theta$ range of $20-60^{\circ}$, with a step size of $0.02^{\circ}$ and step duration of $0.5 \mathrm{~s}$

The mean crystallite size $(D)$ of the particles was calculated from the XRD line-broadening measurement from the Scherrer equation (Azaroff 1968):

$$
D=\frac{0 \cdot 89 \lambda}{\beta \cos \theta},
$$

where $\lambda$ is the wavelength $(\mathrm{CuK} \alpha), \beta$ the full width at half-maximum of the HA (211) line and $\theta$ the diffraction angle.

The fraction of crystalline phase $\left(X_{\mathrm{c}}\right)$ of the HA powders was evaluated by the following equation (Landi et al 2000)

$$
X_{\mathrm{c}}=\frac{1-v_{112 / 300}}{I_{300}},
$$

where $I_{300}$ is the intensity of (300) diffraction peak and $V_{112 / 300}$ the intensity of the hollow between (112) and (300) diffraction peaks of HA.

The particle size distribution of the powder was obtained using a condensation particle counter (GRIMM Aerosol Technik, Gmbh, Germany (serial no 5400)). The Fourier transform infrared spectroscopy (FT-IR) was done with Nexus 6700 FTIR (Thermo-Nicolet, Inc.) equipped with an attenuated total reflectance (ATR) accessory (Smart Miracle, PIKE Tech.).

\section{Results and discussion}

The reactions involved in the formation of HA during the sol-gel preparation and drying can be expressed as follows

$$
\begin{aligned}
& \mathrm{H}_{3} \mathrm{PO}_{4}+3 \mathrm{NH}_{4} \mathrm{OH} \rightarrow\left(\mathrm{NH}_{4}\right)_{3} \mathrm{PO}_{4}+3 \mathrm{H}_{2} \mathrm{O}, \\
& 6\left(\mathrm{NH}_{4}\right)_{3} \mathrm{PO}_{4}+10 \mathrm{Ca}\left(\mathrm{NO}_{3}\right)_{2} \cdot 4 \mathrm{H}_{2} \mathrm{O} \rightarrow \\
& \mathrm{Ca}_{10}\left(\mathrm{PO}_{4}\right)_{6}(\mathrm{OH})_{2}+20 \mathrm{NH}_{4} \mathrm{NO}_{3} .
\end{aligned}
$$

The formation of $20 \mathrm{NH}_{4} \mathrm{NO}_{3}$ (ammonium nitrate) byproduct was removed by repeated washing with double distilled water.

Figure 2a shows the XRD pattern of HA from 200$800^{\circ} \mathrm{C}$. The determined amounts of crystallinity and cry- 

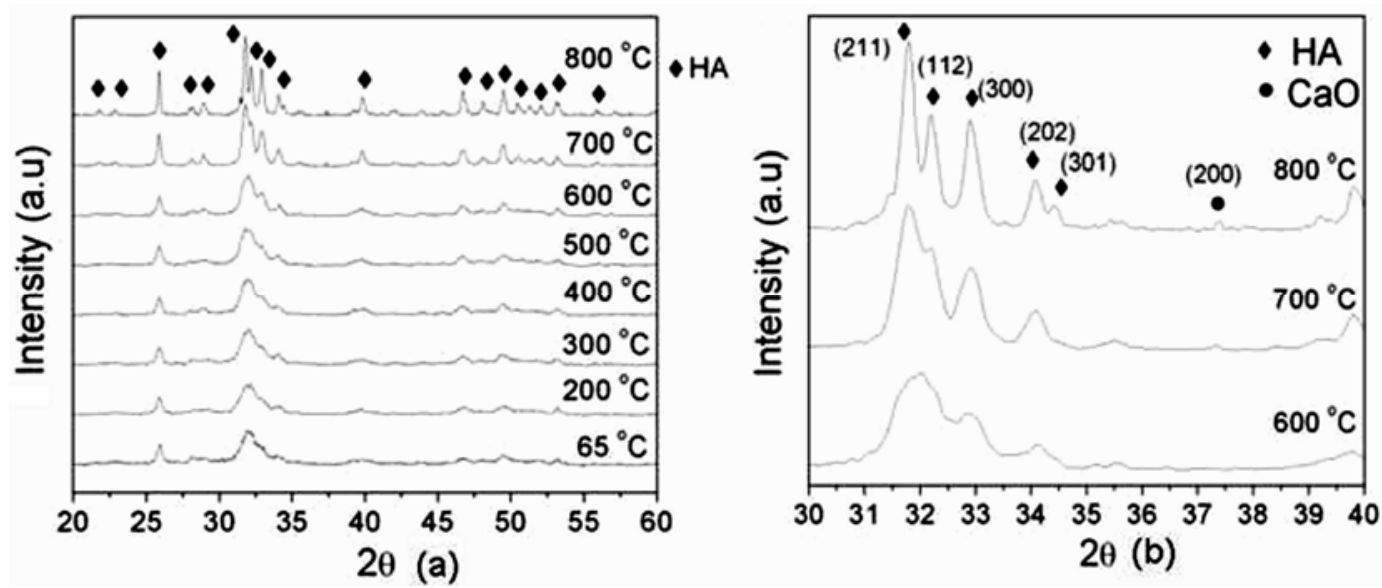

Figure 2. XRD patterns of HA powders (a) calcined at different temperatures and (b) showing presence of minor $\mathrm{CaO}$ phase at 700 and $800^{\circ} \mathrm{C}$.

Table 1. Table showing the crystallinity of HA and comparing the particle size obtained from XRD and PSD at different calcination temperatures.

\begin{tabular}{lccc}
\hline $\begin{array}{l}\text { Calcination } \\
\text { temperature }\left({ }^{\circ} \mathrm{C}\right)\end{array}$ & Crystallinity $(\%)$ & $\begin{array}{c}\text { Crystallite } \\
\text { size, } D(\mathrm{~nm})\end{array}$ & PSD* $(\mathrm{nm})$ \\
\hline 65 & $6 \pm 1 \cdot 1$ & $18 \pm 1 \cdot 5$ & 20 \\
200 & $12 \pm 2 \cdot 5$ & $24 \pm 1 \cdot 3$ & 32 \\
300 & $33 \pm 2 \cdot 2$ & $28 \pm 2 \cdot 0$ & - \\
400 & $44 \pm 3 \cdot 5$ & $31 \pm 1 \cdot 9$ & 37 \\
500 & $57 \pm 2 \cdot 7$ & $28 \pm 2 \cdot 8$ & - \\
600 & $64 \pm 3 \cdot 4$ & $39 \pm 2 \cdot 2$ & 45 \\
700 & $78 \pm 4 \cdot 0$ & $54 \pm 3 \cdot 1$ & - \\
800 & $88 \pm 2 \cdot 5$ & $61 \pm 1 \cdot 5$ & 58 \\
\hline
\end{tabular}

*Particle size value obtained from centre of skewed distribution curve in figure 4 .

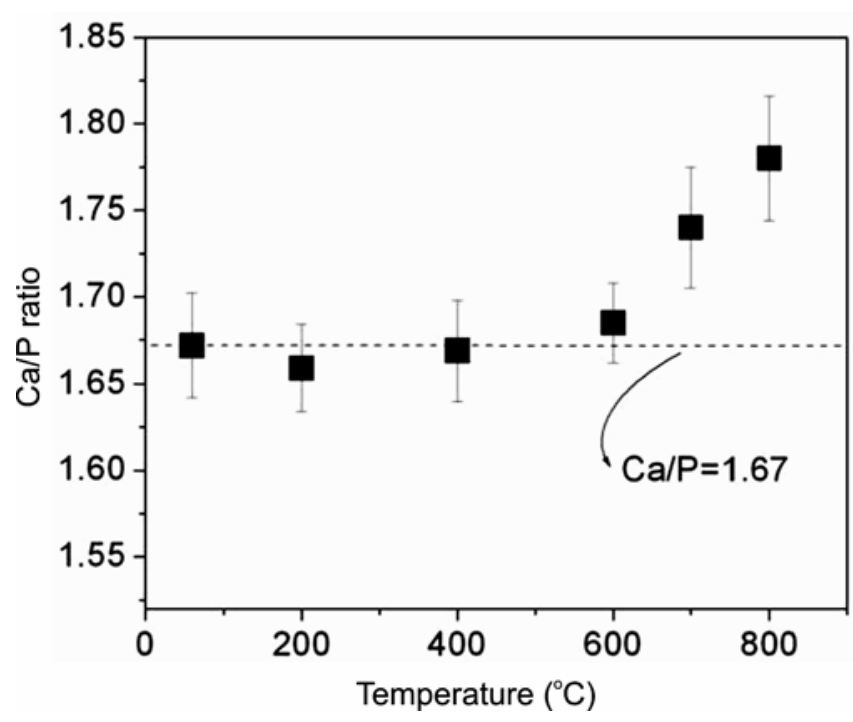

Figure 3. Plot of variation of $\mathrm{Ca} / \mathrm{P}$ with calcination temperature.

stallite size (determined by Scherrer equation) from XRD of five calcined HA samples for each temperature are given in table 1 . It could be observed that the increase in HA crystallinity with the increase in calcination temperature is not linear. Similar phenomenon was observed by Bouyer et al (2000). It was also reported that HA calcined at higher temperatures exhibiting good crystallinity, shows little or no activity towards bioresorption, which is important for the formation of chemical bonding with surrounding hard tissues (Aoki 1994; Currey 2001). Thus the amorphous HA powders that were obtained at lower temperatures in this study are expected to be more metabolically active than the fully developed crystalline hydroxyapatite structure which otherwise is nonsoluble in physiological environment (Kim et al 2000). XRD patterns of the dried HA gel powder calcined at temperatures $600{ }^{\circ} \mathrm{C}$ and below showed mainly broad peaks of HA and no characteristic peaks of impurities were observed, indicating that the product was of high purity. Heating $\mathrm{HA}$ powder at $700^{\circ} \mathrm{C}$ and above induced a high crystalline $\mathrm{HA}$ diffraction peaks together with minor $\mathrm{CaO}$ peaks (figure $2 \mathrm{~b})$. The volume fraction of $\mathrm{CaO}\left(V_{\mathrm{CaO}}\right)$ was calculated using the following equation (Balakrishnan et al 2007) 

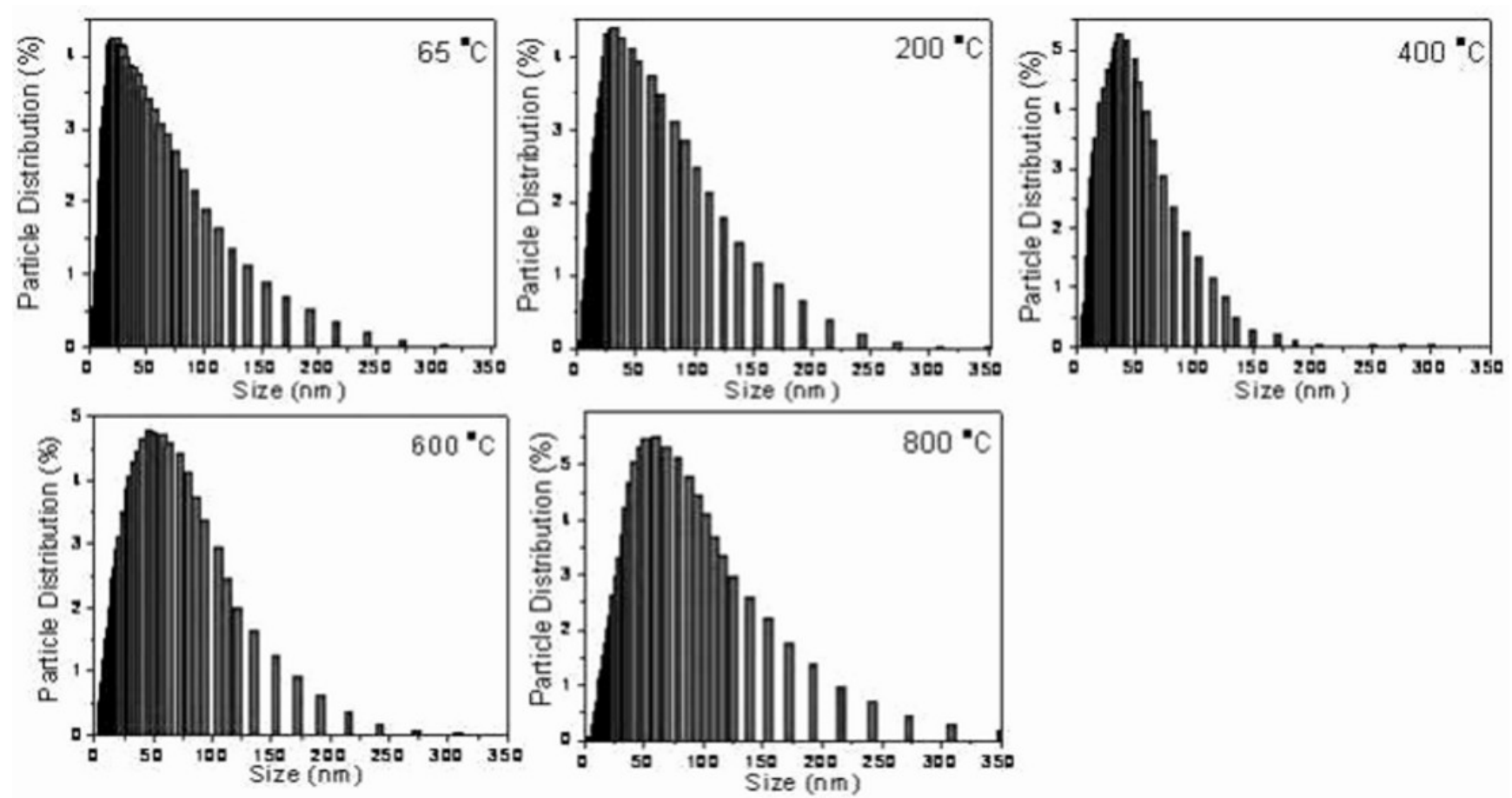

Figure 4. Plot showing the variation in particle size distribution with the change in calcination temperature.

$$
V_{\mathrm{CaO}}=\frac{I_{\mathrm{CaO}_{1}}+I_{\mathrm{CaO}_{2}}}{I_{\mathrm{CaO}_{1}}+I_{\mathrm{CaO}_{2}}+I_{\mathrm{HA}}}
$$

where $I_{\mathrm{CaO}_{1}}$ and $I_{\mathrm{CaO}_{2}}$ are the intensities of the two strongest peaks of $\mathrm{CaO}$ phase, $I_{\mathrm{HA}}$ the intensity of strongest peak of HA phase. The small amount of $\mathrm{CaO}$ at 700 and $800^{\circ} \mathrm{C}$ was found to be $\sim 0.5 \pm 0 \cdot 2$ and $2 \pm 0.5 \%$, respectively. (Note: Because of the very low intensity of $\mathrm{CaO}$ peaks, $I_{\mathrm{CaO}_{2}}=0$ was taken).

The $\mathrm{Ca} / \mathrm{P}$ stoichiometry of calcined $\mathrm{HA}$ at different temperatures (five samples each) (figure 3) was analysed using EDX. Analysing figures $2 \mathrm{~b}$ and 3, it can be seen that $\mathrm{HA}$ powder with a $\mathrm{Ca} / \mathrm{P}$ ratio near to 1.67 i.e. at temperature $600^{\circ} \mathrm{C}$ and below, showed no $\mathrm{CaO}$ contents and that with a $\mathrm{Ca} / \mathrm{P}$ ratio near to 1.75 and above, showed the formation of minor amounts of $\mathrm{CaO}$ i.e. for calcined samples at $700^{\circ} \mathrm{C}$ and above. Other researchers have also reported similar formation of $\mathrm{CaO}$ in sol-gel processing of HA (Lopatin et al 1998; Varma et al 1998). Studies by Chai and Ben-Nissan (1999) indicate that phosphoruscontaining precursors have high potential for volatilization above $650^{\circ} \mathrm{C}$ (Szu et al 1992), hence $\mathrm{Ca}\left(\mathrm{NO}_{3}\right)_{2}$ molecules may not get completely incorporated into the complex which is evident by higher $\mathrm{Ca} / \mathrm{P}$ molar ratio (figures $2 \mathrm{~b}$ and 3 ) at $700^{\circ} \mathrm{C}$ and above.

The particle size distribution (PSD) plot (figure 4) showed a skewed distribution which centred to larger particle size with the increase in temperature. The PSD value centred for each temperature was found to be in proximity with the (table 1) crystallite size obtained from

the Scherrer equation. Figure 5(a and $b$ ) shows the TEM image of the $\mathrm{HA}$ calcined at $600^{\circ} \mathrm{C}$ for 30 min with prolate spheroidal phase structure (figure $5 \mathrm{~b}$ ). Certain agglomeration (figure 5a) of HA particles was observed. The nucleation and growth of HA with temperature can be described by nucleation-aggregation-agglomerationgrowth mechanism theory explained earlier (Randolph and Larson 1986; Rodríguez et al 1998). According to this mechanism, HA particle goes through following steps: (a) nucleation and growth to form HA nanocrystallites, (b) aggregation of elemental nanocrystals by molecular attractions (Gomez et al 2001) of different nanometric/colloidal scale forces which cause surface free energy minimization, (c) further crystal growth, at a constant residual supersaturation, acting as cementing agent inside the aggregates to form agglomerate. The increase in particle size with temperature takes place by aggregation of these agglomerated particles to form secondary particle. This has been schematically represented in figure 6.

FT-IR patterns presented in figure 7 confirm the formation of $\mathrm{HA}$ calcined at $600^{\circ} \mathrm{C}$. The spectra possessed a very weak band at $3720 \mathrm{~cm}^{-1}$, sharp and strong band at $3572 \mathrm{~cm}^{-1}$ and a weak broad band ranging between 3550 and $3350 \mathrm{~cm}^{-1}$. The 3720 and $3572 \mathrm{~cm}^{-1}$ bands correspond to $\mathrm{OH}^{-}$group, and the broad band at 3550$3350 \mathrm{~cm}^{-1}$, to strongly adsorbed and/or bound $\mathrm{H}_{2} \mathrm{O}$ (Elliot 1994). $\mathrm{H}_{2} \mathrm{O}$ band was also observed at $1650 \mathrm{~cm}^{-1}$. A strong band of $\mathrm{PO}_{4}^{3-}$ group was also seen at 1037 and $967 \mathrm{~cm}^{-1}$. The bands obtained for respective phosphate 


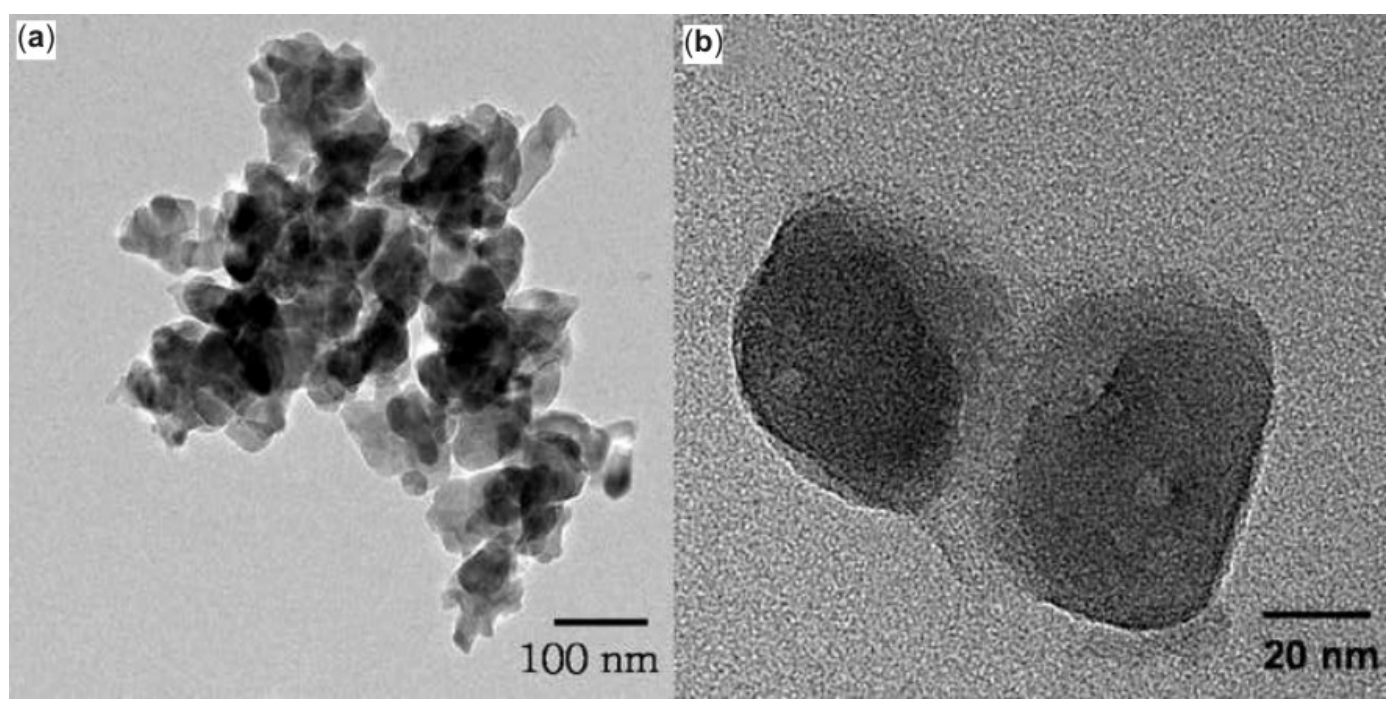

Figure 5. TEM image of calcined HA powders at $600^{\circ} \mathrm{C}$ showing (a) certain agglomeration and (b) morphology and size.

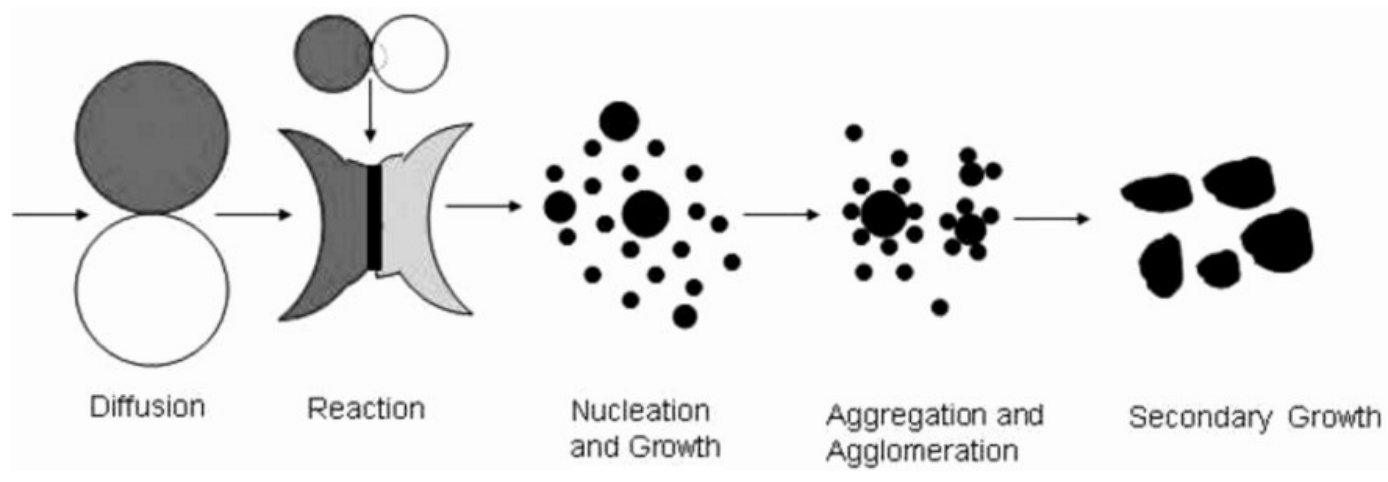

Figure 6. Schematic representation of nucleation and growth of HA (Randolph and Larson 1986; Rodríguez et al 1998).

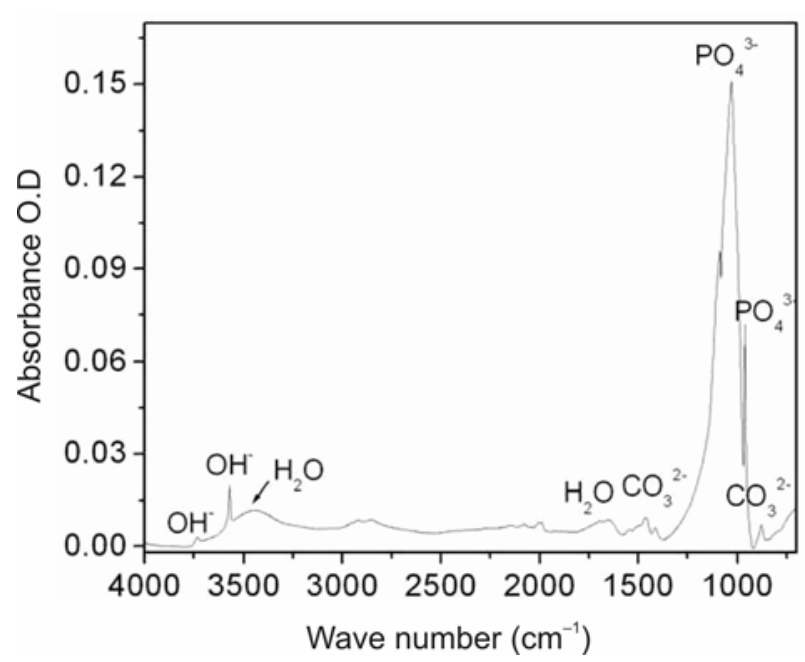

Figure 7. FT-IR patterns showing the formation of HA calcined at $600^{\circ} \mathrm{C}$.

and hydroxyl groups of pure HA, were in agreement with other published data (Montel et al 1980; Rehman and
Bonfield 1997). A weak band of $\mathrm{CO}_{3}^{2-}$ was detected in the region around 1465 and $875 \mathrm{~cm}^{-1}$. The band at $875 \mathrm{~cm}^{-1}$ indicates $n 2$ mode of $\mathrm{CO}_{3}^{2-}$ group (Elliott 1994; Emerson and Fischer 1962) and it suggests a minor amount of B-type carbonate substitution i.e. small part of the $\mathrm{PO}_{4}$ (B-type) groups in the apatitic structure was replaced by $\mathrm{CO}_{3}$. The characteristic bands from inorganic carbonate ion suggest that carbon gets dissolved in the organics from atmosphere and does not pyrolyze completely and may instead dissolve into the HA crystal. Since carbonates are constituents of bone structures (Rajabi-Zamani et al 2008), the presence of $\mathrm{CO}_{3}$ may improve the bioactivity of HA rather than being a cause of concern.

\section{Conclusions}

In this study, the synthesis of a nanostructured hydroxyapatite powder via sol-gel method is reported using calcium and phosphorous precursors. This process showed that high purity product of nano-HA powders could be 
obtained at low temperatures. The crystallinity, particle size and $\mathrm{Ca} / \mathrm{P}$ ratio of the resulting nanoparticles were found to be dependent on the calcination temperature. When $\mathrm{Ca} / \mathrm{P}$ ratio exceeded 1.75 , formation of $\mathrm{CaO}$ phase was observed, which was attributed to phosphorous volatilization. FTIR results showed dissolution of small amount of $\mathrm{CO}_{3}^{2-}$ into the $\mathrm{HA}$ crystal, possibly due to dissolution of $\mathrm{CO}_{2}$ from atmosphere during calcinations at $600^{\circ} \mathrm{C}$. The method of synthesis showed that the biocompatible nanocrystals $(20-60 \mathrm{~nm})$ of HA, with varying degree of crystallinity, can be effectively synthesized using this simple technique.

\section{References}

Afshar A, Ghorbani M, Ehsani N, Saeri M R and Sorrell C C 2003 Mater. Des. 24197

Aoki H 1994 Medical applications of hydroxyapatite (Tokyo: Ishiyaku EuroAmerica)

Azaroff L A 1968 Elements of X-ray crystallography (New York: McGraw-Hill)

Balakrishnan A, Panigrahi B B, Chu M C, Yoon K J, Kim T N and Cho S J 2007 J. Mater. Res. 222550

Bouyer E, Gitzhofer F and Boulos M I 2000 J. Mater. Sci. Mater. Med. 11523

Chai C S and Ben-Nissan B 1999 J. Mater. Sci. Mater. Med. 10 465

Currey J 2001 Nature 414699

Dean-Mo L, Troczynski T and Tseng W J 2001 Biomaterials 22 1721

Dean-Mo L, Quanzu Y, Tom T and Wenjea J T 2002 Biomaterials 231679

Ebaretonbofa E and Evans J G 2002 J. Porous Mater. 9257

Elliott J C 1994 Structure and chemistry of the apatites and other calcium orthophosphates (Amsterdam: Elsevier)

Emerson W H and Fischer E E 1962 Arch. Oral Biol. 7671

Gomez-Morales J, Torrent-Burgues J and Rodriguez-Clemente R 2001 Cryst. Res. Technol. 361065

Hench L L 1998 J. Am. Ceram. Soc. 811705
Itokazu M, Yang W, Aoki T and Kato N 1998 Biomaterials 19 817

Kawasaki T 1999 J. Chromatogr. 544147

Kim H M 2003 J. Curr. Opin. Solid State Mater. Sci. 7289

Kim H M, Kim Y, Park S J, Rey C, Lee H M, Gimcher M J and Ko J S 2000 Biomaterials 211129

Kim I S and Kumta P N 2004 Mater. Sci. Eng. B111 232

Landi E, Tampieri A, Celotti G and Sprio S 2000 J. Eur. Ceram. Soc. 202377

LeGeros R Z 1991 Calcium phosphates in oral biology and medicine (Basel: H.M. Myers) p. 154

Li S H, De Wijn J R, Layrolle P and de Groot K J 2002 Biomed. Mater. Res. 1109

Lopatin C M, Pizziconi V, Alford T L and Laursen T 1998 Thin Solid Films 326227

Masahiro Y, Hiroyuki S, Kengo O and Koji I 1994 J. Mater. Sci. 293399

Minguez F, Agra M, Luruena S, Ramos C and Prieto J 1990 Drugs Exp. Clin. Res. 16231

Montel G, Bonel G, Trombe J C, Heughebaert J C and Rey C 1980 Pure Appl. Chem. 52973

Murugan R and Ramakrishna S 2004 Biomaterials 253073

Rajabi-Zamani A H, Behnamghader A and Kazemzadeh A 2008 Mater. Sci. Eng. C28 1326

Randolph A D and Larson M A 1986 Theory of particulate processes (New York: Academic Press) 2nd edn

Rehman I and Bonfield W 1997 J. Mater. Sci., Mater. Med. 81

Rodríguez-Clemente R, López-Macipe A, Gómez-Morales J, Torrent-Burgués J and Castãno V M 1998 J. Eur. Ceram. Soc. 181351

Saeri M R, Afshar A, Ghorbani M, Ehsani N and Sorrell C C 2003 Mater. Lett. 574064

Shih W J, Yung-Feng C, Moo-Chin W and Min-Hsiung H 2004 J. Cryst. Growth 270211

Silva C C, Pinheiro A G, Miranda M A R, Góes J C and Sombra A S B 2003 Solid State Sci. 5553

Szu S P, Klein L C and Greenblatt M 1992 J. Non-Cryst. Solids 14321

Varma H K, Kalkura S N and Sivakumar R 1998 Ceram. Int. 24 467 